Arab Univ. J. Agric. Sci., Ain Shams Univ., Cairo, 14(1), 281-287, 2006

\title{
PHYSICAL AND STRUCTURAL PROPERTIES OF THE PROMISING EGYPTIAN LONG STAPLE COTTON CROSS (GIZA 89 X GIZA 86)
}

\author{
Nadia S. Abd El-Gawad ${ }^{1}$
}

\begin{abstract}
A promising cotton inbred line characterized by high yielding ability, earliness in maturity and better fiber quality was developed via pedigree selection from the subsequent segregating generations of a cross between the two long-staple cvs.; Giza 89 and Giza 86 by the Cotton Breeding Section of the Cotton Research Institute. The purpose of this investigation aimed at assessment of the superiority of the physical and fine structural properties of the promising line derived from the cross (Giza $89 \mathrm{x}$ Giza 86) over its parents. The results indicated that:

- The promising line surpassed its parents in upper half mean length, uniformity index, fiber strength, fiber elongation, micronaire value, maturity ratio, hair weight, dry fiber ribbon width, swollen fiber diameter, convolution number $/ \mathrm{cm}$., reversals number/ $\mathrm{cm}$. and yarn strength.

- There were highly significant positive correlations between upper half mean length, uniformity index, convolution number $/ \mathrm{cm}$., fiber bundle strength and yarn strength.

- Highly significant negative correlations exhisted between dry fiber ribbon width, swollen fiber diameter, reversals number and bundle strength.

The promising line is now under propagation for growing as a commercial cultivar and would replace both parents in their growing areas.
\end{abstract}

Keywords: Cotton, Promising cross, Physical properties, Structural properties

\section{INTRODUCTION}

Breeding Egyptian cotton is directed mainly towards introducing higher yielding cultivars with improved fiber properties. The use of desirable parents characterized by high yield and good fiber quality in hybridization could enhance the performance of new recombinants. The progress of any breeding program depends on available genetic information. The hybridization-selection method has been utilized effectively in many instances and has been responsible for develop-

1- Cotton Research Institute, Agric. Res. Center, Giza, Egypt

(Received October 12, 2005)

(Accepted November 19, 2005) 
ing most the present commercial cultivars in most of cotton growing countries. AlDidi, (1972) reported that all the commercial cultivars grown in Egypt today were produced by hybridization except Dendera, which is the only one, produced by individual plant selection from Giza 3 . Performance of the promising cotton cross was studied by several workers Awad et al (1996); Haikal et al (1996) and El-Helow et al (2003). The acknowledged reference method for maturity and fineness measurements on cotton is Image Analysis method. Thibodeaux et al (2000). Image Analysis has improved determinations of fiber biological fineness and maturity but it remain too slow and limited with respect to sample size. Huang and $\mathrm{Xu}$ (2002) reported that the Image analysis longitudinal measurements were correlated well with the data obtained from other methods.

\section{MATERIAL AND METHODS}

The Cotton Breeding Research Section at Giza is still fully depending on hybridization followed by the pedigree method for breeding and production of the alternative varieties. A new promising line was derived from a cross between the two long staple cultivars, Giza 89 and Giza 86.

Lint cotton samples of the promising inbred line and its parents were obtained from the different trials of Cotton Breeding Research Section during 2003 season. Upper half mean length (millimeter), length uniformity index, fiber tensile strength (g./tex) and fiber elongation were measured using HVI 900 according to (ASTM: D 2253-86, 1998) Micronaire reading, maturity ratio and fineness (linear density) in millitex were measured by Micromat tester (new F/M T instrument) according to (ASTM: D 3818-79, 1998). The biological fineness (dry fiber ribbon width and swollen fiber diameter in micron) and fiber structural (convolution number/cm. and reversals number $/ \mathrm{cm}$.) were measured from the Image analysis with computer system according to Huang and Xu (2002). Yarn strength was measured according to (ASTM: D 1578-67, 1998).

The samples were tested under controlled atmospheric conditions of $65 \pm$ $2 \%$ relative humidity and $70 \pm 2^{\circ} \mathrm{F}$ temperature at the Cotton Technology Research Institute, Giza, Egypt.

The obtained data were subjected to statistical analysis of variance according to Snedecor and Cochran (1976), L.S.D. test was used for comparing the different means. Simple correlation analysis according to Draper and Smith (1966) were performed with a computerized SAS program.

\section{RESULTS AND DISCUSSION}

The statistical analysis of cotton fiber properties and yarn strength are given in Table (1). The results showed considerable differences between the promising line and its parents in most of the studied properties. These differences were significant at $5 \%$ level.

Comparing the promising line derived from the cross Giza 89 and Giza 86, data in Table (1) indicated that the promising cross surpassed its parents in upper half mean length, uniformity index, fiber strength, fiber elongation, micronaire reading, maturity ratio, hair weight. 
Table 1. Means of fiber properties for the promising line as compared to its parents Giza 89 and Giza 86

\begin{tabular}{|lcccc|}
\hline \multicolumn{1}{|c}{ Fiber properties } & $\begin{array}{c}\text { Promising line } \\
\text { derived from } \\
\text { Giza } 89 \times \text { Giza } 86\end{array}$ & $\begin{array}{c}\text { Giza } \\
89\end{array}$ & $\begin{array}{c}\text { Giza } \\
86\end{array}$ & $\begin{array}{c}\text { LSD at } \\
5 \% \\
\text { level }\end{array}$ \\
\hline Upper half mean Length (mm) & 33.12 & 32.12 & 33.06 & 0.1180 \\
Uniformity Index (\%) & 87.50 & 86.28 & 86.72 & 0.2627 \\
Fiber strength (g/tex) & 45.14 & 42.06 & 44.12 & 0.2222 \\
Elongation \% & 7.20 & 7.14 & 7.02 & 0.1866 \\
Micronaire reading & 4.2 & 4.4 & 4.5 & 0.0907 \\
Maturity ratio & 0.97 & 0.93 & 0.89 & 0.0305 \\
Hair weight (millitex) & 172 & 174 & 173 & 2.2782 \\
\hline
\end{tabular}

Data in Table (2) show fiber fine structural properties (dry fiber ribbon width, swollen fiber ribbon width, convolution number/cm. and reversals number $/ \mathrm{cm}$.) for the promising line and its parents. The statistical analysis showed significant differences between the promising line and its parents in favour of this line with regard to dry fiber ribbon width, swollen fiber diameter, convolution number/ $\mathrm{cm}$., reversals structural number $/ \mathrm{cm}$. and yarn strength.

Simple correlations coefficients between fiber properties and mechanical properties (fiber and yarn strength) for the promising line and its parents are shown in Table (3). The results showed highly significant positive correlation between upper half mean length, uniformity index, convolution number $/ \mathrm{cm}$. and fiber bundle strength. While there are highly significant negative correlation between dry fiber ribbon width, swollen fiber diameter, reversals number and fiber bundle strength. On the other hand there are highly significant positive correlations between upper half mean length, uniformity index, convolution number/cm., fiber bundle strength and yarn strength. Whenever there is highly significant negative correlation between dry fiber ribbon width, swollen fiber diameter, reversals number $/ \mathrm{cm}$. and yarn strength.

The high value of yarn strength of the promising line could be related to their long, strong and fine fibers (higher number of fibers in yarn cross section) that surpassed the patents in each category.

\section{CONCLUSIONS}

It could be concluded that the promising inbred line derived from the cross between the long-staple cvs.; Giza 89 and Giza 86 surpassed its parents in fiber and fine structural properties, as well as, yarn strength. Therefore, it is recommended to replace both parents in their growing areas. 
Table 2. Means of fiber fine structural properties for the promising line as compared to its parents Giza 89 and Giza 86

\begin{tabular}{|lcccc|}
\hline \multicolumn{1}{|c}{ Fiber properties } & $\begin{array}{c}\text { Promising line } \\
\text { derived from } \\
\text { Giza } 89 \times \text { Giza } 86\end{array}$ & $\begin{array}{c}\text { Giza } \\
89\end{array}$ & $\begin{array}{c}\text { Giza } \\
86\end{array}$ & $\begin{array}{c}\text { LSD at } \\
5 \% \\
\text { level }\end{array}$ \\
\hline Image analysis data & 14.3 & 15.5 & 14.8 & 0.1331 \\
Dry fiber ribbon width $(\mu)$ & 17.7 & 18.6 & 17.9 & 0.1445 \\
Swollen fiber diameter $(\mu)$ & 37.6 & 36.7 & 33.9 & 0.6853 \\
Convolution number/cm. & 7.2 & 9.3 & 8.4 & 0.1943 \\
Reversals number/cm. & 2564 & 2475 & 2540 & 11.7923 \\
Yarn strength. & & & & \\
\hline
\end{tabular}

Table 3. Simple correlation coefficients between various characters and mechanical properties for the promising line and its parents

\begin{tabular}{|lll|}
\hline \multicolumn{1}{|c}{ Properties } & \multicolumn{2}{c|}{ Correlation values } \\
\cline { 2 - 3 } & Fiber strength & Yarn strength \\
\hline Upper half mean length $(\mathrm{mm})$ & $0.921^{* *}$ & $0.972^{* *}$ \\
Uniformity Index & $0.975^{* *}$ & $0.695^{* *}$ \\
Dry fiber ribbon width $(\mu)$ & $-0.975^{* *}$ & $-0.768^{* *}$ \\
Swollen fiber diameter $(\mu)$ & $-0.965^{* *}$ & $-0.858^{* *}$ \\
Convolution number/cm. & $0.928^{* *}$ & $0.893^{* *}$ \\
Reversals number/cm. & $-0.894^{* *}$ & $-0.571^{*}$ \\
Fiber strength $(\mathrm{g} / \mathrm{tex})$ & - & $0.993^{* *}$ \\
\hline
\end{tabular}

*, **: Denote significant at 5\% and $1 \%$ levels of probability, respectively 


\section{REFERENCES}

\begin{abstract}
Al-Didi, M.A. (1972). History of Egyptian cotton varieties. Egypt. Cotton Gaz., 58: 33-56.

Awad, M.M.; S.I.S. Abou-Zahra; F.S. Mustafa; M.M. Awaad; S.A.S. Mohamed and F. El-Anani (1996). Breeding potential of the promising families drived from the cross Giza 83 x Giza 80 of long staple cotton cultivated in Middle and Upper Egypt. Egypt. J. Appl. Sci., 11(9): 27-36.
\end{abstract}

A.S.T.M. (1998). American Society for Testing and Materials. Standards on Textile Materials. D: 1578-67; 2253-86 and 3818-79. Philadelphia 3 , Pa, U.S.A.

Draper, N.R. and H. Smith (1966). Applied Regression Analysis, 407 pp. John Wiley and Sons, Inc., New York.

El-Helow, S.S.; A.H. Mohamed; A.A.M. Awad and M.A.M. Allam (2003). Breeding potential of the promis- ing hybrid Giza 84 x (Giza 74 x Giza 68) of the Extra long staple cotton. Egypt. J. Agric. Res., 81(2): 647-658.

Haikal, I.M.; Y.T. Atta; M.A. Rahoumah; M.A. Megahed; S.A. ElShaarawy and M.A.A. Raafat (1996). The new long staple Egyptian cotton variety Giza 86. Egypt. J. Appl. Sci., 11(3): 130-138.

Huang, Y. and B. Xu. (2002). Image Analysis for cotton fibers. Part 1: longitudinal measurement. Textile Res. J., 72 (8): 713-720.

Snedecor, G.W. and W.G. Cochran (1976). Statistical Methods. Iowa State Univ. Press, Ames, Iowa, U.S.A.

Thibodeaux, D.; K. Rajasekaran; J.G. Montalvo and T. Von Hoven (2000). The status of cotton maturity measurements in the new millennium. Proceedings International Cotton Conference: 115-128, Bremen. 


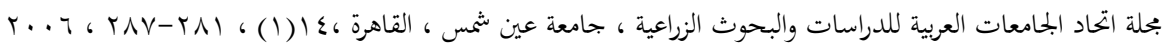

صفات فيزيائية وتركيبية للهجين المبشر بين صنفى القطن المصرى

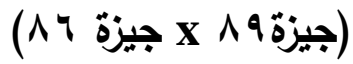

$[1 \wedge]$

\section{نادية صلاح الدين عبد الجواد'}

1 - معهد بحوث القطن - مركز البحوث الزراعية - الجيزة - مصر لادراد

تـم إجر اء هذا البحـث على سـلالة نقيـة الصفات الدقيقة و التركيبيـة (عرض الثـريط

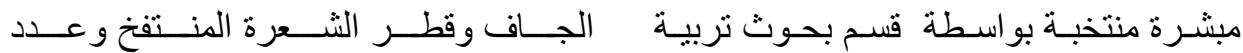

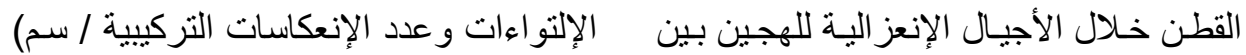

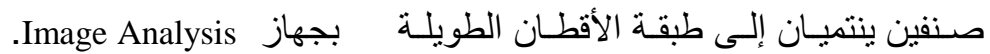

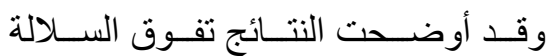

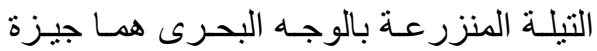

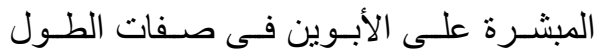

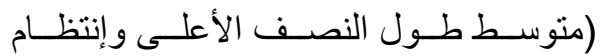

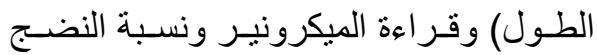

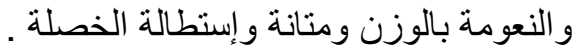

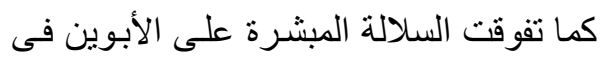

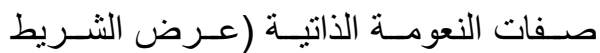

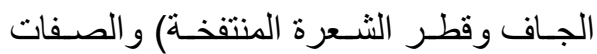
التركيبية (و عدد الإلتواءات و وعدد الإنعكاسات التركيبية / سم).

وجدت علاقة موجبة و عالية المعنوية بين

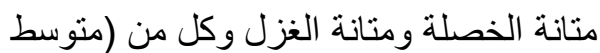
طول النصف الأعلى ومعامل الإنتظام لطول الخول التيلة عدد الإلتو اءات / سم بينما كانت العلاتلة الإنة

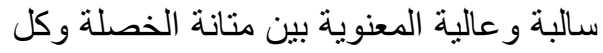

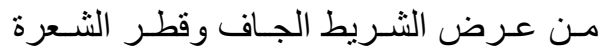
المنتفخة و عدد الإنعكاسات التركيبية / سم.

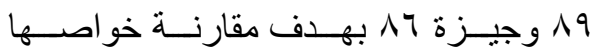

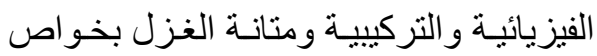

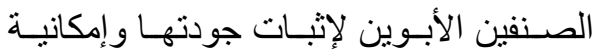

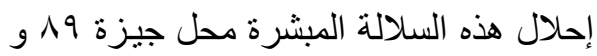
جيزة 14 فى أماكن زر اعتهما. أخذت عبنات من كل من السلالة المبشرة

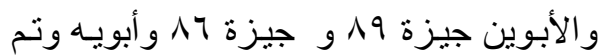

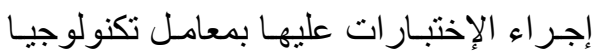

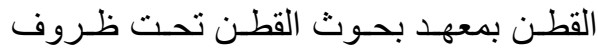

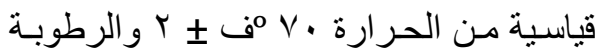

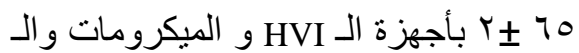
Image analysis وقد نم در اسة الصفات الفيزيائية (متوسط الصالة طول النصف الأعلى ومعامل الإنتظام لطول

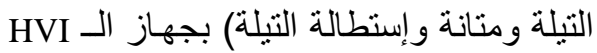

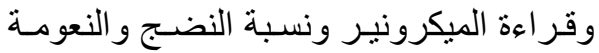

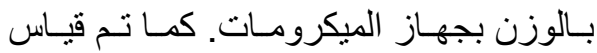




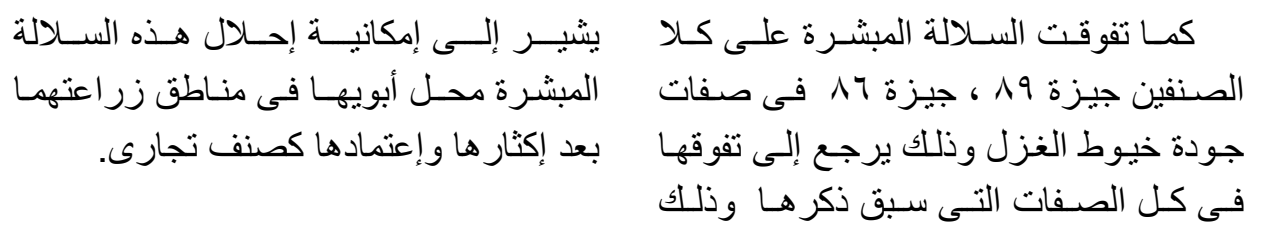

$$
\begin{aligned}
& \text { تحكيم: أ.د عبد المقصود محروس المر اكبى } \\
& \text { أ.د عـادل متـولى سمـره }
\end{aligned}
$$

